\title{
Comparing projections of future changes in runoff from hydrological and biome models in ISI-MIP
}

\author{
J. C. S. Davie ${ }^{1}$, P. D. Falloon ${ }^{1}$, R. Kahana ${ }^{1}$, R. Dankers ${ }^{1}$, R. Betts ${ }^{1}$, F. T. Portmann ${ }^{2},{ }^{9}$, D. Wisser ${ }^{3}$, D. B. Clark ${ }^{4}$,

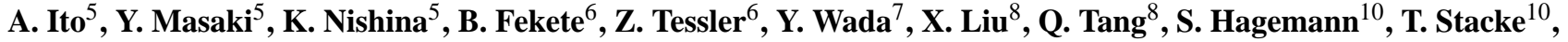 \\ R. Pavlick ${ }^{11}$, S. Schaphoff ${ }^{12}$, S. N. Gosling ${ }^{13}$, W. Franssen ${ }^{14}$, and N. Arnell ${ }^{15}$ \\ ${ }^{1}$ Met Office Hadley Centre, Exeter, UK \\ ${ }^{2}$ Biodiversity and Climate Research Centre (LOEWE BiK-F) \& Senckenberg Research Institute and Natural History \\ Museum, Frankfurt am Main, Germany \\ ${ }^{3}$ Center for Development Research, University of Bonn, Germany \\ ${ }^{4}$ Centre for Ecology and Hydrology, Wallingford, UK \\ ${ }^{5}$ Center for Global Environmental Research, National Institute for Environmental Studies, Tsukuba, Japan \\ ${ }^{6}$ Civil Engineering Department, The City College of New York CUNY, New York, USA \\ ${ }^{7}$ Department of Physical Geography, Faculty of Geosciences, Utrecht University, the Netherlands \\ ${ }^{8}$ Institute of Geographic Sciences and Natural Resources Research, Chinese Academy of Sciences, Beijing, China \\ ${ }^{9}$ Institute of Physical Geography, Goethe University Frankfurt, Frankfurt am Main, Germany \\ ${ }^{10}$ Max Planck Institute for Meteorology, Hamburg, Germany \\ ${ }^{11}$ Max Planck Institute for Biogeochemistry, Jena, Germany \\ ${ }^{12}$ Potsdam Institute for Climate Impact Research, Potsdam, Germany \\ ${ }^{13}$ School of Geography, University of Nottingham, Nottingham, UK \\ ${ }^{14}$ Wageningen University and Research Centre, Wageningen, the Netherlands \\ ${ }^{15}$ Walker Institute, University of Reading, UK
}

Correspondence to: J. C. S. Davie (jemma.davie@metoffice.gov.uk) and P. D. Falloon (pete.falloon@metoffice.gov.uk)

Received: 31 January 2013 - Published in Earth Syst. Dynam. Discuss.: 13 February 2013

Revised: 23 August 2013 - Accepted: 28 August 2013 - Published: 10 October 2013

\begin{abstract}
Future changes in runoff can have important implications for water resources and flooding. In this study, runoff projections from ISI-MIP (Inter-sectoral Impact Model Intercomparison Project) simulations forced with HadGEM2-ES bias-corrected climate data under the Representative Concentration Pathway 8.5 have been analysed for differences between impact models. Projections of change from a baseline period (1981-2010) to the future (2070-2099) from 12 impacts models which contributed to the hydrological and biomes sectors of ISI-MIP were studied. The biome models differed from the hydrological models by the inclusion of $\mathrm{CO}_{2}$ impacts and most also included a dynamic vegetation distribution. The biome and hydrological models agreed on the sign of runoff change for most regions of the world. However, in West Africa, the hydrological models projected drying, and the biome models a moistening. The biome models
\end{abstract}

tended to produce larger increases and smaller decreases in regionally averaged runoff than the hydrological models, although there is large inter-model spread. The timing of runoff change was similar, but there were differences in magnitude, particularly at peak runoff. The impact of vegetation distribution change was much smaller than the projected change over time, while elevated $\mathrm{CO}_{2}$ had an effect as large as the magnitude of change over time projected by some models in some regions. The effect of $\mathrm{CO}_{2}$ on runoff was not consistent across the models, with two models showing increases and two decreases. There was also more spread in projections from the runs with elevated $\mathrm{CO}_{2}$ than with constant $\mathrm{CO}_{2}$. The biome models which gave increased runoff from elevated $\mathrm{CO}_{2}$ were also those which differed most from the hydrological models. Spatially, regions with most difference between model types tended to be projected to have most 
effect from elevated $\mathrm{CO}_{2}$, and seasonal differences were also similar, so elevated $\mathrm{CO}_{2}$ can partly explain the differences between hydrological and biome model runoff change projections. Therefore, this shows that a range of impact models should be considered to give the full range of uncertainty in impacts studies.

\section{Introduction}

Assessments of future hydrological changes are important due to the effects that changes in water availability, flooding and drought can have on society (Kundzewicz et al., 2007). At the global scale, projections of future freshwater availability may be provided by a number of different modelling approaches (Bates et al., 2008), each of which may potentially produce different results, even when driven by the same forcing data. For example, the WaterMIP intercomparison (Haddeland et al., 2011) studied two types of water models. They classified the models into global hydrological models (GHMs, which tend to be focused on water resources and represent lateral transfers of water), and land surface models (LSMs, which typically calculate vertical exchanges of heat, carbon and water), although these categories are not exclusive and some GHMs contain features of LSMs and viceversa. These two categories of model showed differences in simulating aspects of the present-day water balance (Haddeland et al., 2011), linked both to the representation of snow processes in mid-high latitudes, and canopy evaporation over the Amazon. Similarly, a recent study comparing multiple GHMs driven by an ensemble of GCMs (Hagemann et al., 2013) found a large spread in future runoff responses, with GHM choice being an important factor. The spread in future runoff projections was dominated by GHM choice over central Amazonia and the high latitudes (Hagemann et al., 2013). This suggests that differences between models are a major source of uncertainty, and that climate change impact studies need to consider both multiple climate models and multiple impact models.

The Inter-Sectoral Impact Model Intercomparison Project (ISI-MIP) (Warszawski et al., 2013) is a community-driven modelling effort with the goal of providing cross-sectoral global impact assessments, based on the newly developed climate [representative concentration pathways (RCPs)] and socio-economic [shared socio-economic pathways (SSPs)] scenarios (Moss et al., 2010). Based on common background scenarios (climate and socio-economic), a quantitative estimate of impacts and uncertainties for different sectors and from multiple impact models were derived. Within ISI-MIP, future projections of runoff (Schewe et al., 2013) were provided by both models contributing to the hydrological sector (which mostly do not include vegetation dynamics) and the biome sector (which do include vegetation dynamics).

\subsection{Impact of vegetation change on runoff}

Vegetation dynamics may alter the future response of runoff since changing vegetation patterns (in response to future climate) may alter the fluxes of energy and water in several ways. Firstly, plant structural changes, such as changing plant functional types (PFTs), or changes in leaf area index (LAI) may alter evapotranspiration rates and albedo. Secondly, changes in plant productivity and leaf area index may result from the changing climate, which may similarly alter evapotranspiration rates and albedo. Thirdly, increased $\mathrm{CO}_{2}$ concentrations will alter plant growth, photosynthesis, and water use efficiency, which may also alter evapotranspiration rates (Falloon and Betts, 2006; Gedney et al., 2006; Betts et al., 2007), and albedo. Since any changes in evapotranspiration caused by plant responses to increasing $\mathrm{CO}_{2}$ have to be balanced by runoff, changes in runoff may result.

Elevated $\mathrm{CO}_{2}$ is generally considered to have two opposing impacts on runoff through changes to evapotranspiration. Firstly, $\mathrm{CO}_{2}$ fertilisation of photosynthesis, may increase plant productivity and leaf area index, thereby also increasing the possible evapotranspiration from the canopy (Betts et al., 2007; Alo and Wang, 2008), and thus decreasing runoff. Secondly, $\mathrm{CO}_{2}$ may also inhibit evapotranspiration by reducing stomatal conductance at the leaf level (Gedney et al., 2006; Betts et al., 2007; Cao et al., 2010). Recent studies have generally found overall increases in runoff resulting from elevated $\mathrm{CO}_{2}$ concentrations (Gedney et al., 2006; Betts et al., 2007), although the relative size of the two opposing effects may vary (Alkama et al., 2010), particularly regionally and seasonally. The $\mathrm{CO}_{2}$ fertilisation of photosynthesis and reduced stomatal conductance can also lead to increased soil moisture contents (Niklaus and Falloon, 2006), leading to further increases in NPP (Friend et al., 2013). Even within one impact model, estimates of future water stress have been found to be highly sensitive to $\mathrm{CO}_{2}$ impacts on runoff (Wiltshire et al., 2013).

\subsection{Present study}

The aims of this study are set out in the following questions:

- How do the runoff responses projected by biome and hydrological models, from the ISI-MIP ensemble, differ in terms of the direction, magnitude, spatial and seasonal patterns of change?

- How does the inclusion of elevated $\mathrm{CO}_{2}$ and its effects in the biome models affect the runoff response in the direction, magnitude and pattern of change?

- How does the inclusion of a dynamic vegetation distribution affect the runoff response in direction, magnitude and pattern of change? 
- Can the effects on runoff of elevated $\mathrm{CO}_{2}$ and a changing vegetation distribution explain the differences between hydrological and biome models' runoff projections?

\section{Methodology}

\subsection{Forcing data}

Runoff data was analysed from all impacts models, contributing to the hydrological or biomes sector, that provided monthly output fields to the ISI-MIP archive from simulations forced with HadGEM2-ES (Collins et al., 2011; Jones et al., 2011; Martin et al., 2011) bias-corrected climate data (Hempel et al., 2013) for the historical period (1971-2004) and the RCP 8.5 future climate scenario (2005-2099). We focussed only on simulations driven by the HadGEM2-ES RCP8.5 experiments for several reasons. This setup provided the largest data set for analysis in ISI-MIP, and the largest impacts of vegetation change on runoff may be expected under the stronger RCP8.5 forcing scenario. While the application of non-bias-corrected GCM data can result in large uncertainty in impact simulations (Gosling et al., 2010; Ehret et al., 2012), the application of bias correction in the ISI-MIP forcing data set may largely have removed any impact of differences between GCMs in the present-day baseline (Hempel et al., 2013). Unrouted runoff, as opposed to (routed) discharge was analysed in the present study since discharge data was not available from all of the biome models studied here. For 2100 compared to the baseline period (1861-1990), in the original HadGEM2-ES simulations, global mean temperatures increased by approximately $6 \mathrm{~K}$ and precipitation by around $6 \%$ (Caesar et al., 2012).

\subsection{Models}

The models whose data was used are described in Table 1. In this study, the models were assigned to two groups, named biome and hydrological models. If a model contributed to the biome sector or both the biome and hydrological sectors of ISI-MIP, it was classified as a biome model. If a model only contributed to the hydrological sector, then it was a hydrological model for the purposes of this study (Fig. 1). This method of grouping the impact models was used to separate the models including vegetation effects on runoff from those which do not. VISIT did not include vegetation dynamics, but did include $\mathrm{CO}_{2}$ impacts, hence its inclusion as a biome model. Due to this, JULES and LPJmL were classified as biome models because their inclusion of $\mathrm{CO}_{2}$ impacts and dynamic vegetation distributions, although they are also full hydrology models. The data used here were global gridded data sets mainly on a $0.5^{\circ}$ latitude-longitude grid, with JULES and JeDi on a $1.25^{\circ} \times 1.875^{\circ}$ latitude-longitude grid.

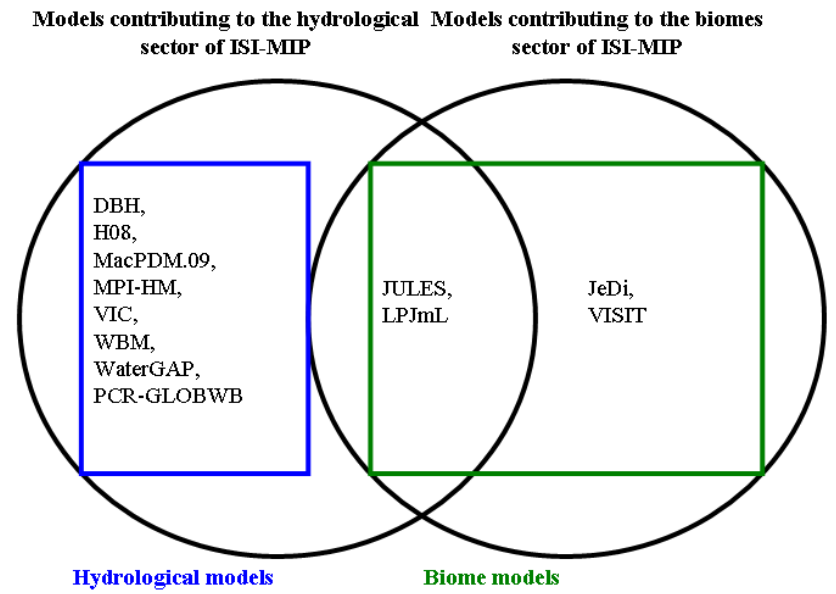

Fig. 1. Venn diagram to show the grouping of the impact models the black circles show which models contributed to the biomes and hydrological sectors of ISI-MIP, with the overlap showing models which contributed output for variables in both sectors. The boxes with coloured outlines show the classification of models into groups within this study - the models within the blue box are included as hydrological models and the models listed within the green box are included as biome models.

\subsection{Experimental setup}

The model runs were set up according to the ISI-MIP simulation protocol (Warszawski et al., 2013) so they were run with comparable settings. As common forcing data was used in all of the model runs, differences between their output came from differences in the impact models - and therefore show the uncertainty in projections based only on the model selected or the setup of the model in the case of sensitivity experiments. The main simulations analysed in this study were the core ISI-MIP runs, provided by the largest set of impact models (Warszawski et al., 2013). For hydrological models, these were naturalised runs with no human impact, and for biome models, these were runs with varying $\mathrm{CO}_{2}$ concentration, specified by the RCP scenario. Sensitivity experiment runs using the biome models were further analysed to investigate the importance of including individual processes. These included model runs with either constant $\mathrm{CO}_{2}$ (concentration kept constant from 2000), static vegetation distribution or both. Table 2 gives an overview of the experiments analysed in this study and shows which models carried out sensitivity experiments. The aim of this study is to show that impact models including carbon dioxide impacts and/or vegetation dynamics may give differing projections to models not considering these, and therefore they should be included in hydrological impact assessments.

\subsection{Evaluation of simulated present-day runoff}

Simple validation of the modelled runoff was carried out, firstly by comparing averaged historical runoff from the 
Table 1. Models used in the present study and their main characteristics (in part, after Haddeland et al. (2011)) $-($ a) $R=$ rainfall rate; $S=$ snowfall rate; $P=$ precipitation (rain or snow distinguished in the model); $T=$ air temperature; Tmax $=$ maximum daily air temperature; Tmin = minimum daily air temperature; $W=$ windspeed; $Q=$ specific humidity; $L W=$ longwave radiation flux (downward); LWnet = longwave radiation flux (net); SW = shortwave radiation flux (downward); and SP = surface pressure; (b) Bulk formula: Bulk transfer coefficients are used when calculating the turbulent heat fluxes; (c) Beta function: runoff is a nonlinear function of soil moisture.

\begin{tabular}{|c|c|c|c|c|c|c|c|c|c|}
\hline Model Name & $\begin{array}{l}\text { Model } \\
\text { time } \\
\text { step }\end{array}$ & $\begin{array}{l}\text { Meteorological } \\
\text { forcing } \\
\text { variables (a) }\end{array}$ & $\begin{array}{l}\text { Energy } \\
\text { ba- } \\
\text { lance }\end{array}$ & $\begin{array}{l}\text { ET } \\
\text { scheme } \\
\text { (b) }\end{array}$ & $\begin{array}{l}\text { Runoff } \\
\text { scheme (c) }\end{array}$ & $\begin{array}{l}\text { Snow } \\
\text { scheme }\end{array}$ & $\begin{array}{l}\text { Vegetation } \\
\text { dyna- } \\
\text { mics }\end{array}$ & $\begin{array}{l}\mathrm{CO}_{2} \\
\text { impacts }\end{array}$ & References \\
\hline \multicolumn{10}{|c|}{ Hydrological models } \\
\hline DBH & $1 \mathrm{~h}$ & $\begin{array}{l}P, T, W, Q, \\
\mathrm{LW}, \mathrm{SW}, \mathrm{SP}\end{array}$ & Yes & $\begin{array}{l}\text { Energy } \\
\text { balance }\end{array}$ & $\begin{array}{l}\text { Infiltration } \\
\text { excess }\end{array}$ & $\begin{array}{l}\text { Energy } \\
\text { balance }\end{array}$ & No & No & Tang et al. $(2006,2007)$ \\
\hline VIC & Daily/3 h & $\begin{array}{l}P, \text { Tmax, } \\
\text { Tmin, } W, Q, \\
\text { LW, SW, SP }\end{array}$ & No & $\begin{array}{l}\text { Penman- } \\
\text { Monteith }\end{array}$ & $\begin{array}{l}\text { Saturation } \\
\text { excess/beta } \\
\text { function }\end{array}$ & $\begin{array}{l}\text { Energy } \\
\text { balance }\end{array}$ & No & No & Liang et al. (1994) \\
\hline WBM & Daily & $P, T$ & No & Hamon & $\begin{array}{l}\text { Saturation } \\
\text { excess }\end{array}$ & $\begin{array}{l}\text { Empirical } \\
T \text { and } \\
P \text { based } \\
\text { formula }\end{array}$ & No & No & Vörösmarty et al. (1998) \\
\hline $\begin{array}{l}\text { Mac- } \\
\text { PDM.09 }\end{array}$ & Daily & $\begin{array}{l}P, T, \text { LWnet, } \\
\text { SW }\end{array}$ & No & $\begin{array}{l}\text { Penman- } \\
\text { Monteith }\end{array}$ & $\begin{array}{l}\text { Saturation } \\
\text { excess/beta } \\
\text { function }\end{array}$ & $\begin{array}{l}\text { Degree- } \\
\text { day }\end{array}$ & No & No & $\begin{array}{l}\text { Gosling et al. (2010); } \\
\text { Gosling and Arnell (2011) }\end{array}$ \\
\hline MPI-HM & Daily & $\begin{array}{l}P, T, W, Q, \\
\mathrm{LW}, \mathrm{SW}, \mathrm{SP}\end{array}$ & No & $\begin{array}{l}\text { Penman- } \\
\text { Monteith }\end{array}$ & $\begin{array}{l}\text { Saturation } \\
\text { excess/beta } \\
\text { function }\end{array}$ & $\begin{array}{l}\text { Degree- } \\
\text { day }\end{array}$ & No & No & $\begin{array}{lrr}\text { Hagemann and } & \text { Gates } \\
(2003) ; \quad \text { Stacke } & \text { and } \\
\text { Hagemann (2012) }\end{array}$ \\
\hline WaterGAP & Daily & $\begin{array}{l}P, T, \text { LWnet, } \\
\text { SW }\end{array}$ & No & $\begin{array}{l}\text { Priestley- } \\
\text { Taylor }\end{array}$ & Beta function & $\begin{array}{l}\text { Degree- } \\
\text { day }\end{array}$ & No & No & $\begin{array}{l}\text { Alcamo et al. (2003); Döll } \\
\text { et al. (2003, 2012); Flörke } \\
\text { et al. (2013) }\end{array}$ \\
\hline H08 & Daily & $\begin{array}{l}R, S, T, W, Q, \\
\mathrm{LW}, \mathrm{SW}, \mathrm{SP}\end{array}$ & Yes & $\begin{array}{l}\text { Bulk } \\
\text { formula }\end{array}$ & $\begin{array}{l}\text { Saturation } \\
\text { excess/beta } \\
\text { function/ } \\
\text { subsurface } \\
\text { flow }\end{array}$ & $\begin{array}{l}\text { Energy } \\
\text { balance }\end{array}$ & No & No & Hanasaki et al. $(2008 \mathrm{a}, \mathrm{b})$ \\
\hline $\begin{array}{l}\text { PCR- } \\
\text { GLOBWB }\end{array}$ & Daily & $P, T$ & No & Hamon & $\begin{array}{l}\text { Saturation ex- } \\
\text { cess/infiltration } \\
\text { excess }\end{array}$ & $\begin{array}{l}\text { Degree- } \\
\text { day }\end{array}$ & No & No & $\begin{array}{l}\text { Wada et al., 2011, 2013a; } \\
\text { van Beek et al., } 2011\end{array}$ \\
\hline \multicolumn{10}{|l|}{ Biome models } \\
\hline LPJmL & Daily & $\begin{array}{l}P, T, \text { LWnet, } \\
\text { SW }\end{array}$ & No & $\begin{array}{l}\text { Priestley- } \\
\text { Taylor }\end{array}$ & $\begin{array}{l}\text { Saturation } \\
\text { excess }\end{array}$ & $\begin{array}{l}\text { Degree } \\
\text { day }\end{array}$ & Yes & Yes & $\begin{array}{l}\text { Bondeau et al. (2007); } \\
\text { Rost et al. (2008) }\end{array}$ \\
\hline JULES & $1 \mathrm{~h}$ & $\begin{array}{l}R, S, T, W, Q, \\
\text { LW, SW, SP }\end{array}$ & Yes & $\begin{array}{l}\text { Penman- } \\
\text { Monteith }\end{array}$ & $\begin{array}{l}\text { Infiltration } \\
\text { excess/Darcy }\end{array}$ & $\begin{array}{l}\text { Energy } \\
\text { balance }\end{array}$ & Yes & Yes & $\begin{array}{l}\text { Clark et al. (2011); Best } \\
\text { et al. (2011) }\end{array}$ \\
\hline VISIT & Monthly & $P, T, Q, \mathrm{SW}$ & Yes & $\begin{array}{l}\text { Penman- } \\
\text { Monteith }\end{array}$ & $\begin{array}{l}\text { Bucket (sim- } \\
\text { plified satura- } \\
\text { tion excess) }\end{array}$ & $\begin{array}{l}\text { Ambient } \\
\text { tempera- } \\
\text { ture }\end{array}$ & No & Yes & Ito and Inatomi (2011) \\
\hline JeDi & Daily & $P, T, \mathrm{LW}, \mathrm{SW}$ & No & $\begin{array}{l}\text { Priestley- } \\
\text { Taylor }\end{array}$ & $\begin{array}{l}\text { Saturation } \\
\text { excess/beta } \\
\text { function }\end{array}$ & $\begin{array}{l}\text { Degree- } \\
\text { day }\end{array}$ & Yes & Yes & Pavlick et al. (2013) \\
\hline
\end{tabular}


Table 2. Model simulations analysed in the present study (all driven by ISI-MIP forcing data for HadGEM2-ES historic and RCP8.5 scenarios) - (a) nosoc: naturalized runs, with no human impact, no irrigation, and no population/GDP data prescribed; nolu = no human land use assumed.

\begin{tabular}{|c|c|c|c|c|c|c|c|}
\hline Model name & Main & & & Sensitivity & periments & & \\
\hline & & $\begin{array}{l}\text { Vegetation } \\
\text { dynamics }\end{array}$ & $\begin{array}{l}\mathrm{CO}_{2} \\
\text { impacts }\end{array}$ & $\begin{array}{l}\text { Fixed } \\
\text { vegetation }\end{array}$ & & $\begin{array}{l}\text { Dynamic } \\
\text { vegetation }\end{array}$ & \\
\hline & & & & $\begin{array}{l}\text { Fixed } \\
\mathrm{CO}_{2}\end{array}$ & $\begin{array}{l}\text { Varying } \\
\mathrm{CO}_{2}\end{array}$ & $\begin{array}{l}\text { Fixed } \\
\mathrm{CO}_{2}\end{array}$ & $\begin{array}{l}\text { Varying } \\
\mathrm{CO}_{2}\end{array}$ \\
\hline \multicolumn{8}{|c|}{ Hydrological models } \\
\hline DBH & nosoc & - & - & - & - & - & - \\
\hline VIC & nosoc & - & - & - & - & - & - \\
\hline WBM & nosoc & - & - & - & - & - & - \\
\hline Mac-PDM.09 & nosoc & - & - & - & - & - & - \\
\hline MPI-HM & nosoc & - & - & - & - & - & - \\
\hline WaterGAP & nosoc & - & - & - & - & - & - \\
\hline H08 & nosoc & - & - & - & - & - & - \\
\hline PCR-GLOBWB & nosoc & - & - & - & - & - & - \\
\hline \multicolumn{8}{|l|}{ Biome models } \\
\hline LPJmL & nolu & Yes & Yes & - & - & Yes & Yes \\
\hline JULES & nolu & Yes & Yes & Yes & Yes & Yes & Yes \\
\hline VISIT & nolu & - & Yes & Yes & Yes & - & - \\
\hline JeDI & nolu & Yes & Yes & - & - & Yes & Yes \\
\hline
\end{tabular}

impact models, with the ISLSCP II UNH/GRDC composite monthly runoff (Fekete et al., 2002; Hall et al., 2006; Fekete et al., 1999; Fekete and Vorosmarty, 2011) by calculating global and regional annual averages (Table 3). This showed that globally, the impact models tend to predict higher runoff totals than the GRDC data set. Regionally the impact models also tended to overestimate runoff, with very few model and region combinations giving lower runoff values than the composite runoff field. This, however, is strongly related to the GCM precipitation input; simulated runoff driven by observed precipitation has given values more similar to the GRDC data set in previous studies (van Beek et al., 2011). Secondly, the annual cycles of runoff from the Fekete composite runoff field, for a group of Giorgi regions have been overplotted on annual cycle plots of modelled runoff to compare the timing of runoff throughout the year, which show whether the impact models captured observed seasonality. The timing of runoff projected by the models matches well with ISLSCP II UNH/GRDC composite runoff (Fekete et al., 2002, 1999; Hall et al., 2006; Vörösmarty et al., 1998), although the magnitudes are different, particularly at the peaks, where the models (mainly the biome models) gave generally higher runoff than the composite data set in some regions.

\subsection{Analysis}

Using the full model data set described above, $30 \mathrm{yr}$ averages of annual and monthly runoff for 1981-2010 and 2070-2099 were calculated and the difference between them analysed. Precipitation was largely identical in all of the models since they were driven by the common forcing data, which had a global mean of $893 \mathrm{~mm} \mathrm{yr}^{-1}$ for the land surface during the baseline period (1981-2010), which is within the range of 743-926 $\mathrm{mm} \mathrm{yr}^{-1}$ suggested by Biemans et al. (2009), although the latter used a baseline period of 1979-1999. Very minor differences in the precipitation have arisen through differences in model setup, including grid resolution.

Data was analysed on annual and monthly timescales for land Giorgi regions (Supplementary Fig. 1: Giorgi and Bi, 2005; Ruosteenoja, 2003), in order to compare differences between models across large regions with different climates. As discussed in Meehl et al. (2007), the Giorgi regions have simple shapes and are no smaller than the horizontal scales on which current global climate models are useful for climate simulations (typically judged to be roughly $1000 \mathrm{~km}$ ). This means that the whole global land area could be covered using a manageable number of similarly sized boxes, giving a broader global picture than a selection of river basins. Using regions of similar size also means that in scatter plots with a point representing each region, results are less biased towards giving smaller basins relatively more effect visually per unit area than larger basins. Despite these benefits of using Giorgi regions rather than river basins, regional averages over Giorgi regions may have some deficiencies (Meehl et al., 2007). These are discussed in Sect. 4. 


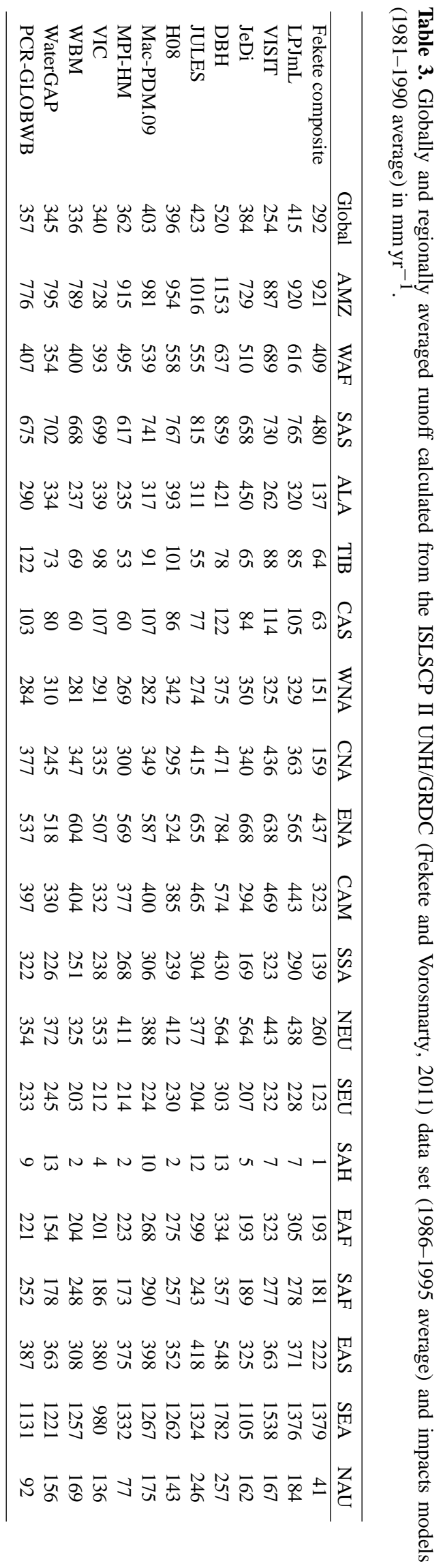



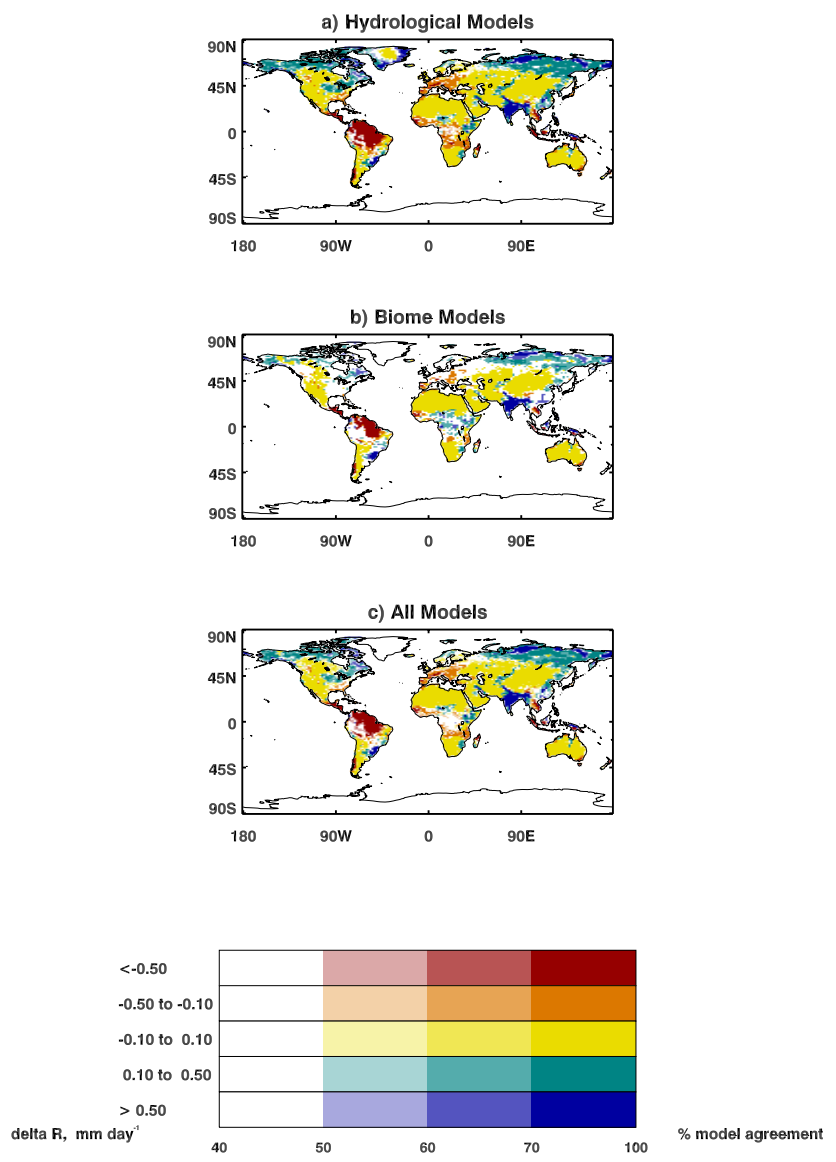

Fig. 2. Ensemble consensus for runoff change between 1981-2010 and 2070-2099 for (a) hydrological models, (b) biome models and (c) all models when forced with HadGEM2-ES RCP8.5 climate. Each colour shows the category of runoff change, while lighter (darker) shades indicate the proportion of models agreeing with that category of change. Runoff changes were calculated individually for each model, and then the consensus across these individual model changes were calculated for hydrological models, biome models and all models.

In order to identify spatial patterns of model agreement, consensus plots (Kaye et al., 2011; McSweeney and Jones, 2013) were created for the biome models and hydrological models separately as well as for the full set of models. These show the proportion of models which agreed on a particular category of runoff change. This was done since averaging over model groups may compromise the physical consistency between variables, and does not show the true behaviour of any particular model outcome (Taylor et al., 2013; Ehret et al., 2012).

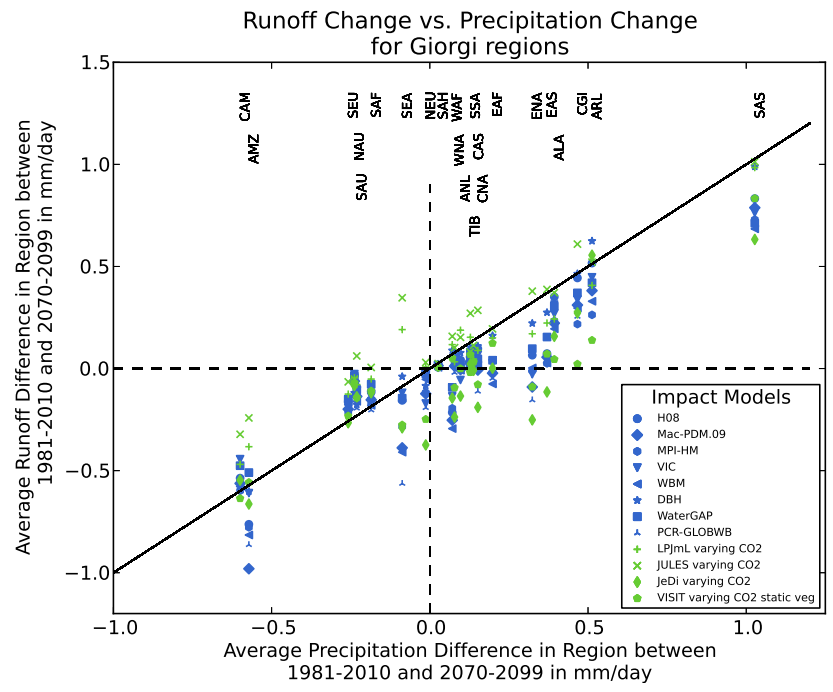

Fig. 3. Scatter plot of precipitation change against runoff change between 1981-2010 and 2070-2099 in mm day ${ }^{-1}$ for the Giorgi regions - including results from all models forced with HadGEM2ES RCP8.5 climate. Solid 1:1 line. Dashed $x=0$ line and $y=0$ line.

\section{Results and discussion}

\subsection{Runoff changes across all models}

There were differences between the runoff projections from the hydrological and biome models (Fig. 2). However, in common with Hagemann et al. (2013) there was a large spread of projections between models (Fig. 3). Within each model category the spread was larger than the difference between the two categories, as well as there being considerable overlap, so the differences largely result from intermodel uncertainty. Haddeland et al. (2011) also found that differences between models in each class were larger than inter-class differences. The direction of projected runoff change tended to be the same for each type of model, but with different magnitude of change (Figs. 2 and 3). The approximately linear positive relationship between annual mean precipitation change and annual mean runoff change showing the dominance of precipitation in controlling the runoff changes (Fig. 3), is in agreement with Betts et al. (2007).

Regional differences in other processes affecting runoff changes are apparent from the dispersion of points about the $1: 1$ line in Fig. 3. An exception to the direction of change being consistent between the model types is in parts of central Africa where biome models showed consensus for increased runoff, while the hydrological models showed consensus for decreased runoff (Fig. 2). In some regions including Europe, central Africa and the Amazon, the hydrological models gave consensus for a drying, whereas the biome models had little agreement as to the projected change. 

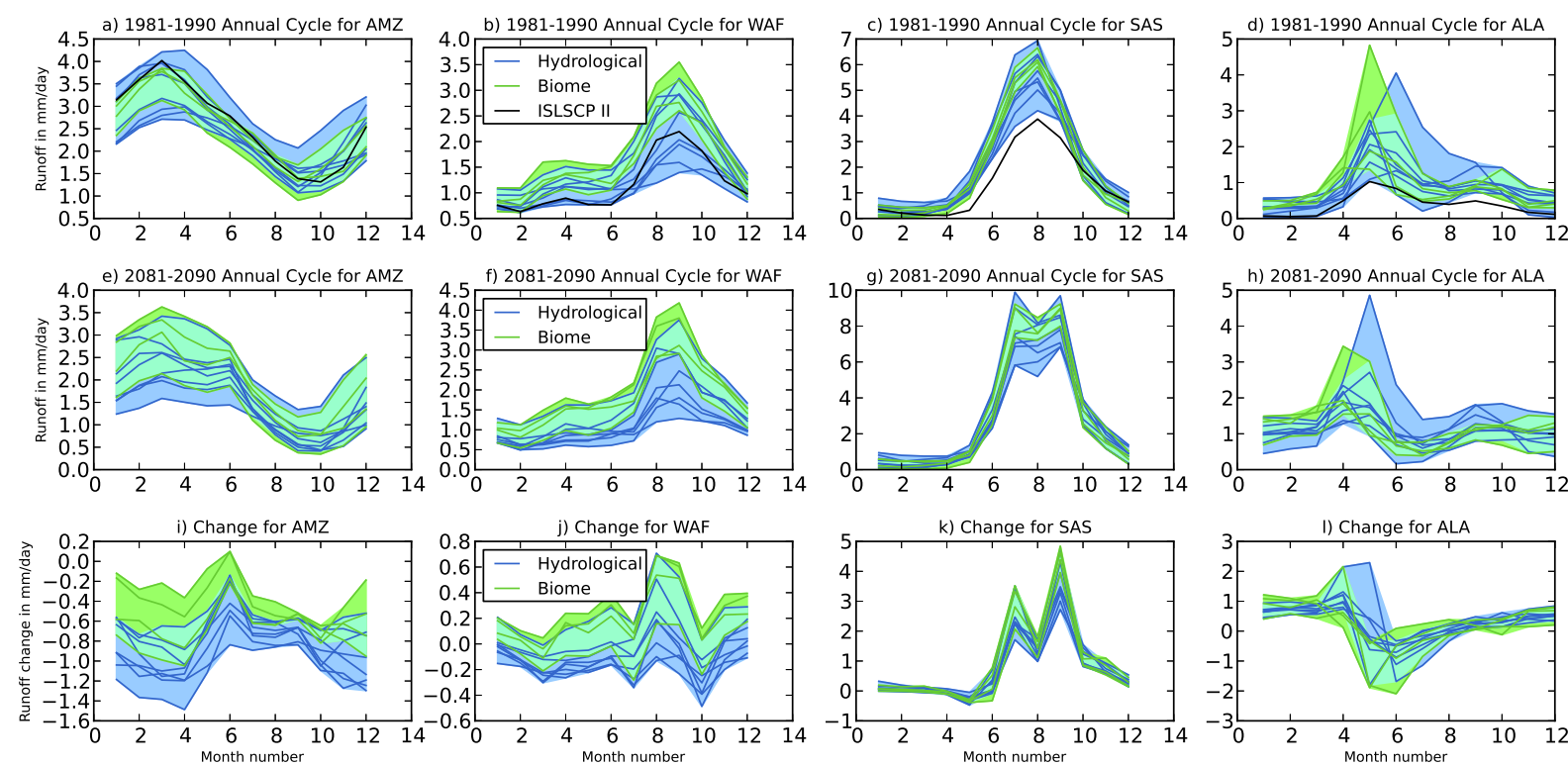

Fig. 4. Annual cycles of runoff for selected Giorgi regions using ISI-MIP (Warszawski et al., 2013) model runs forced with HadGEM2-ES RCP8.5 climate. (a-d): absolute values for 1981-1990, (e-h): absolute values for 2081-2090, (i-l): absolute changes between 1981-1990 and 2081-2090.

The biome models tended to have more increased and less decreased runoff between 1981-2010 and 2070-2099 than the hydrological models, particularly in regions with a large model spread, and when large change was projected (Fig. 3). However, this was not the case for all of the models, as JeDi and VISIT projected larger decreases in some regions. The seasonal patterns of runoff change were reasonably similar for the biome and hydrological models, with the main difference between the model types being the magnitude of changes (Fig. 4). For example, the annual cycle of runoff change for Amazonia shows that the two types of model had a similar shape to the seasonal cycle, but the hydrological models projected larger decreases than the biome models. For Amazonia, Southern Asia and West Africa, regions with pronounced differences, there was most difference between model types at times of peak runoff. Haddeland et al. (2011) found that runoff results for the Amazon were sensitive to the representation of canopy evaporation. Hagemann et al. (2013) also found that spread in runoff projections largely came from model choice over the Amazon and high latitudes. However, it is more difficult to determine differences in the seasonal pattern for Alaska and Western Canada, but both types of model gave a shift to an earlier month of peak runoff.

\subsection{The impact of varying $\mathrm{CO}_{2}$ in biome models}

The biome models tended to be consistent in their individual projections for the direction of runoff change over time, regardless of whether $\mathrm{CO}_{2}$ varied or remained constant (Fig. 5). The projected changes in runoff from the constant $\mathrm{CO}_{2}$ runs tended to be within the range of projected changes

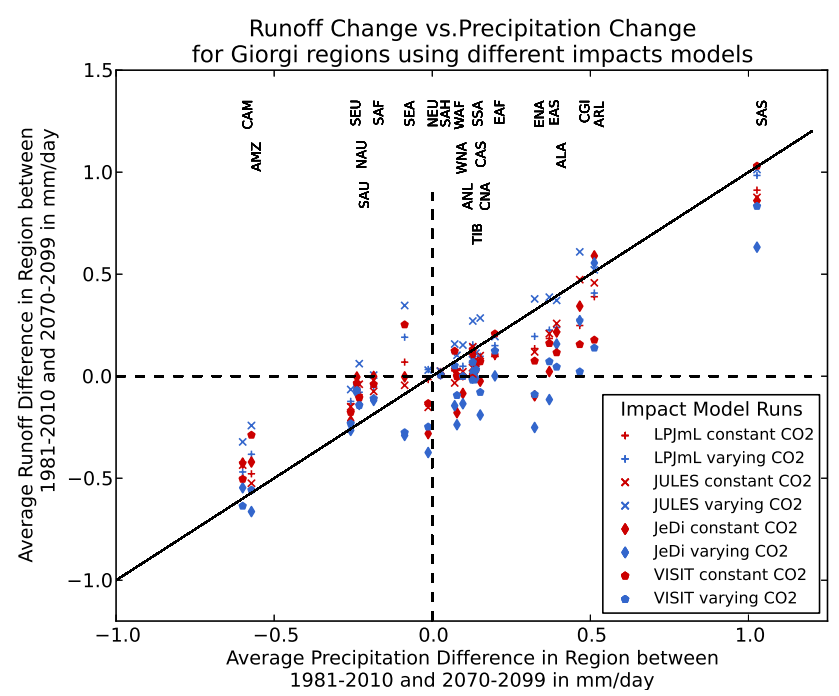

Fig. 5. Scatter plot of precipitation change against runoff change between 1981-2010 and 2070-2099 in $\mathrm{mm} \mathrm{day}^{-1}$ for the Giorgi regions - for models including both varying and constant $\mathrm{CO}_{2}$ forced with HadGEM2-ES RCP8.5 climate. Solid $1: 1$ line. Dashed $x=0$ line and $y=0$ line. 

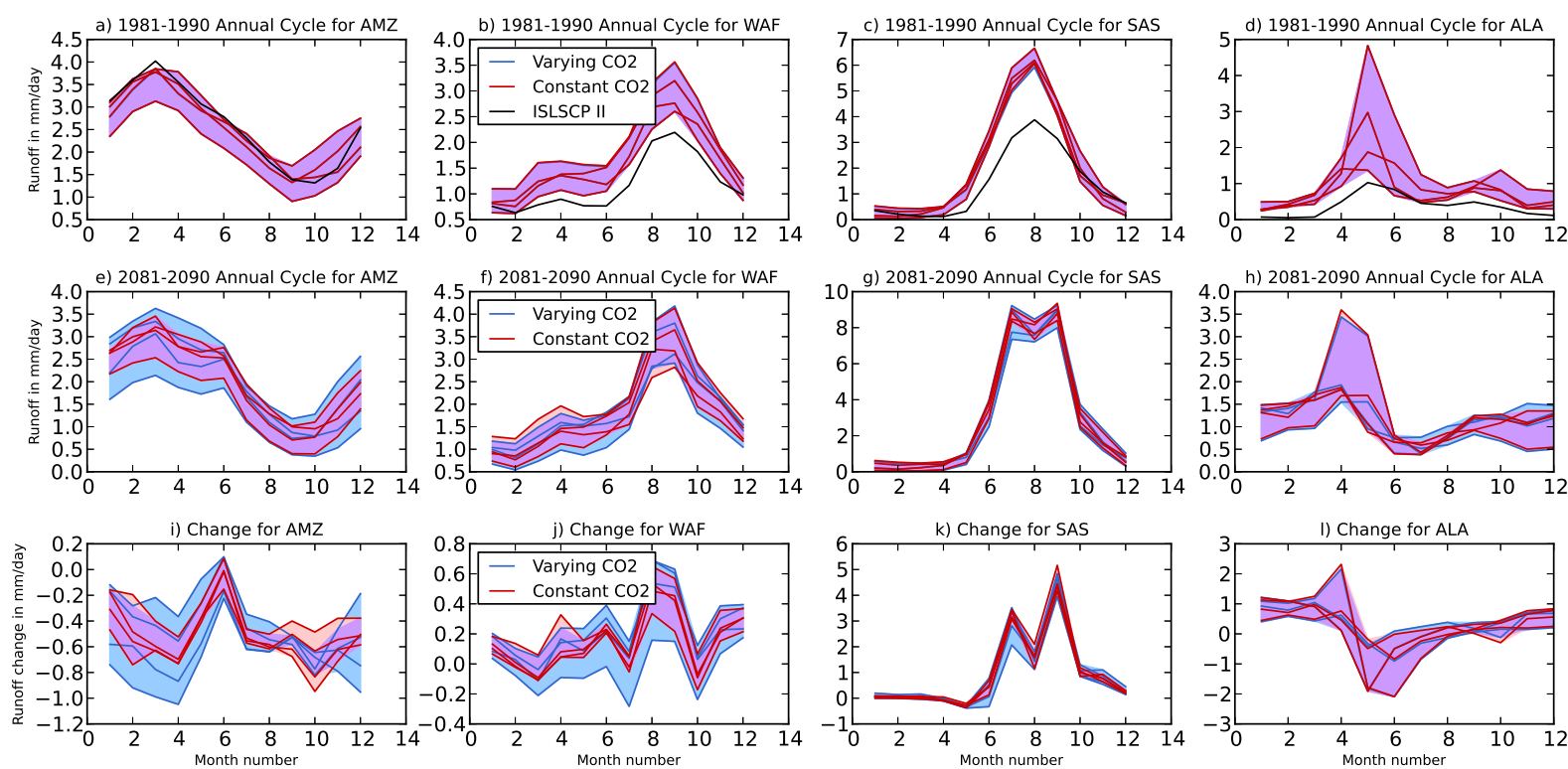

Fig. 6. Annual cycles of runoff for selected Giorgi regions using runs from models including both varying $\mathrm{CO}_{2}$ and constant $\mathrm{CO}_{2}$. Lines represent each varying CO2 run and each constant $\mathrm{CO}_{2}$ run: (a-d): absolute values for 1981-1990, (e-h): absolute values for 2081-2090, (i-l): absolute changes between 1981-1990 and 2081-2090.

from the varying $\mathrm{CO}_{2}$ runs, so the changes in the varying $\mathrm{CO}_{2}$ runs were more spread with smaller and larger magnitude changes than under constant $\mathrm{CO}_{2}$. The biome models did not agree, however, on the direction of change in runoff due to elevated $\mathrm{CO}_{2}$, with two of the models (JULES and LPJmL) showing larger increases and smaller decreases in runoff and the other two (JeDi and VISIT) showing the reverse. The increase in $\mathrm{CO}_{2}$ has competing effects on runoff, and the comparative strengths of these control whether there will be increased or decreased runoff due to elevated $\mathrm{CO}_{2}$. Therefore, these models must have had differently related strengths to produce the opposite overall effects in runoff. Compared to the other biome models, JeDi has a weaker coupling between $\mathrm{CO}_{2}$ and stomatal conductance, leading to smaller reductions in transpiration under increased $\mathrm{CO}_{2}$. However, it produces a similar strength $\mathrm{CO}_{2}$ fertilisation effect to the other models, so the balance between the opposing influences on runoff led to higher transpiration and reduced runoff. Wada et al. (2013b) found reduced irrigation water demand for LPJmL projections with elevated $\mathrm{CO}_{2}$ compared to the constant $\mathrm{CO}_{2}$ projection, which is consistent with our findings. The biome models which differed most from the hydrological models in their runoff projections (Fig. 3) were also those which projected higher runoff from varying $\mathrm{CO}_{2}$ than constant $\mathrm{CO}_{2}$ (Fig. 5). The more similar changes projected by the models' constant $\mathrm{CO}_{2}$ runs showed that some of the uncertainty in biome models' runoff projections was related to processes linking $\mathrm{CO}_{2}$ with runoff.

The effect of elevated $\mathrm{CO}_{2}$ on runoff change was of as large a magnitude as the change projected over time for some models and regions. For example, in the JULES runs, Amazonia (AMZ) was projected to have an average change of $-88.26 \mathrm{~mm} \mathrm{yr}^{-1}$ with varying $\mathrm{CO}_{2}$ and $-191.51 \mathrm{~mm} \mathrm{yr}^{-1}$ with constant $\mathrm{CO}_{2}$. Spatially, the areas where runoff change was most affected by elevated $\mathrm{CO}_{2}$ were very similar between the four biome models (Amazonia, eastern North America, Southeast Asia and central Africa), however with opposing directions of change between models in these regions.

Seasonally, the timing of change in runoff was very similar for model runs with varying $\mathrm{CO}_{2}$ as for those with constant $\mathrm{CO}_{2}$, and the main difference was the magnitude of change at different times of year (Fig. 6). In Amazonia, West Africa and Southern Asia, there was most difference between the varying $\mathrm{CO}_{2}$ and fixed $\mathrm{CO}_{2}$ runoff change projections at times of peak runoff. During the rainy season, evapotranspiration is not limited by soil moisture availability so that plants usually may transpire at their potential rate. Thus, limits on transpiration imposed by the stomatal conductance will directly impact the total amounts of evapotranspiration, and hence runoff.

\subsection{The impact of varying vegetation and $\mathrm{CO}_{2}$ in JULES}

The relative effects of elevated $\mathrm{CO}_{2}$ and changing vegetation on runoff change were analysed using sensitivity experiments carried out with JULES. As in the previous Sect. 3.2, JULES projected greater increases and smaller decreases under elevated $\mathrm{CO}_{2}$. This was regardless of the inclusion of vegetation change, which had a much smaller magnitude 


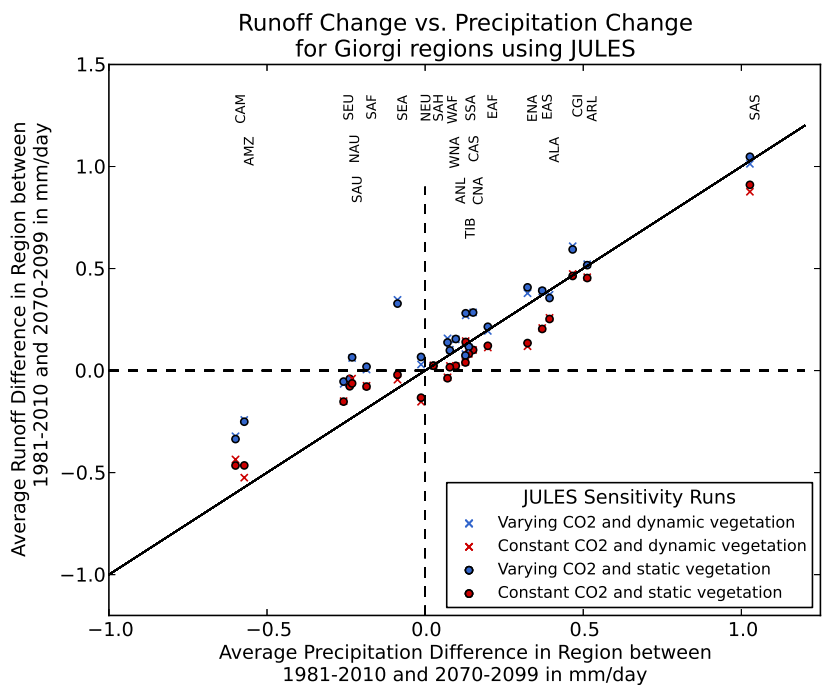

Fig. 7. Scatter plot of precipitation change against runoff change between 1981-2010 and 2070-2099 in $\mathrm{mm} \mathrm{day}^{-1}$ for the Giorgi regions - for the four JULES simulations forced with HadGEM2ES RCP8.5 climate. Solid 1: 1 line. Dashed $x=0$ line and $y=0$ line.

impact on the projections. The impact of vegetation distribution change on projected runoff change varied in direction for different regions (Fig. 7).

There was relatively little change in the vegetation distribution in the model runs (Supplementary Figs. 4 and 5) which accounts for the small effect on runoff. This agrees with Falloon et al. (2012a) who found only small impacts of vegetation change on future (2080s) surface climate. In contrast, in studies where larger vegetation changes were applied, either in palaeoclimate (O'ishi and Abe-Ouchi, 2012; Micheels et al., 2009), at equilibrium in the future (Jones et al., 2009, 2010) or synthetically (Fraedrich et al., 2005), larger impacts on surface climate were observed. There was a larger effect of vegetation change on relative runoff change in regions with lower precipitation (Supplementary Fig. 3), which was also found by Leipprand and Gerten (2006). As well as the magnitude, the seasonal pattern of the effects on runoff change of the two factors also differed. The impact of elevated $\mathrm{CO}_{2}$ was relatively even throughout the year, while the impact of vegetation change varied more seasonally. For example, there was most effect from vegetation change in West Africa between July and September in both the elevated and constant $\mathrm{CO}_{2}$ runs and for Amazonia, there was most effect between January and April in the constant $\mathrm{CO}_{2}$ projection (Fig. 8).

Seasonally, the effect of a changing vegetation distribution varied between regions (Fig. 8). For example, vegetation change gave a larger shift to an earlier peak in spring runoff for Alaska and Western Canada, while the effect was less on the timing of the seasonal cycle and more on the magnitude of the changes for some other regions. Considering the effect of vegetation distribution change and the timing of high and low runoff throughout the year, some regions were projected to experience an increasing effect during high runoff (WAF), and some a decreasing effect (SAS).

Spatially, there was mostly higher runoff projected by the run with dynamic vegetation, particularly over Amazonia and Southeast Asia, but lower runoff projected in a few places than the run with a static vegetation distribution. Over Amazonia (AMZ), there were projected to be smaller decreases in runoff in the JULES run with changing vegetation than the run with static vegetation, with a change from shrubs to trees. Annual evaporation is generally higher in forested catchments compared to non-forested catchments (Zhang et al., 2001), so this change from shrub to trees would be expected to reduce runoff. Therefore, reduced transpiration rates due to elevated $\mathrm{CO}_{2}$ outweighed increases in evapotranspiration due to change in vegetation cover. However, over Europe and parts of eastern North America, the effect on runoff of the change in vegetation type was not outweighed by the effects of $\mathrm{CO}_{2}$ on stomatal conductance. In these regions, a change from needleleaf to broadleaf trees was projected along with reduced runoff, as when fully leafed out, broadleaf trees have twice the albedo and 50-80\% greater evapotranspiration rates than needleleaf trees (Swann et al., 2010).

\subsection{Linking vegetation effects and model differences}

Two of the biome models in this study (JULES and LPJmL) had runoff change projections which were more dissimilar in magnitude of change to the hydrological models' projections than the other two. These were also the biome models which projected increased runoff with elevated $\mathrm{CO}_{2}$, so the inclusion of $\mathrm{CO}_{2}$ processes contributed to the differences between the hydrological models and the biome models in this study. The larger spread of projections from the biome model runs with varying $\mathrm{CO}_{2}$ than with constant $\mathrm{CO}_{2}$ added to the uncertainty of projections and so it is important not to discount these models in hydrological impact studies if the full range of possible outcomes is to be considered. The differences in runoff change projections between runs with varying $\mathrm{CO}_{2}$ and constant $\mathrm{CO}_{2}$ were as large as the change over time in some regions in some model projections. The spatial pattern of where there was most difference between biome and hydrological models' projections and the pattern of where there was most difference by varying $\mathrm{CO}_{2}$ overlapped in Amazonia, central Africa, eastern North America and Southern Asia. Seasonally, both for differences between biome and hydrological models and between varying and constant $\mathrm{CO}_{2}$ model runs, the main differences were the magnitude of changes, rather than the timing. The two comparisons also showed the common pattern that there was most difference at the peaks of runoff for Amazonia, Southern Asia and West Africa. Vegetation change, however, had a much smaller effect on the runoff projections, so contributed 


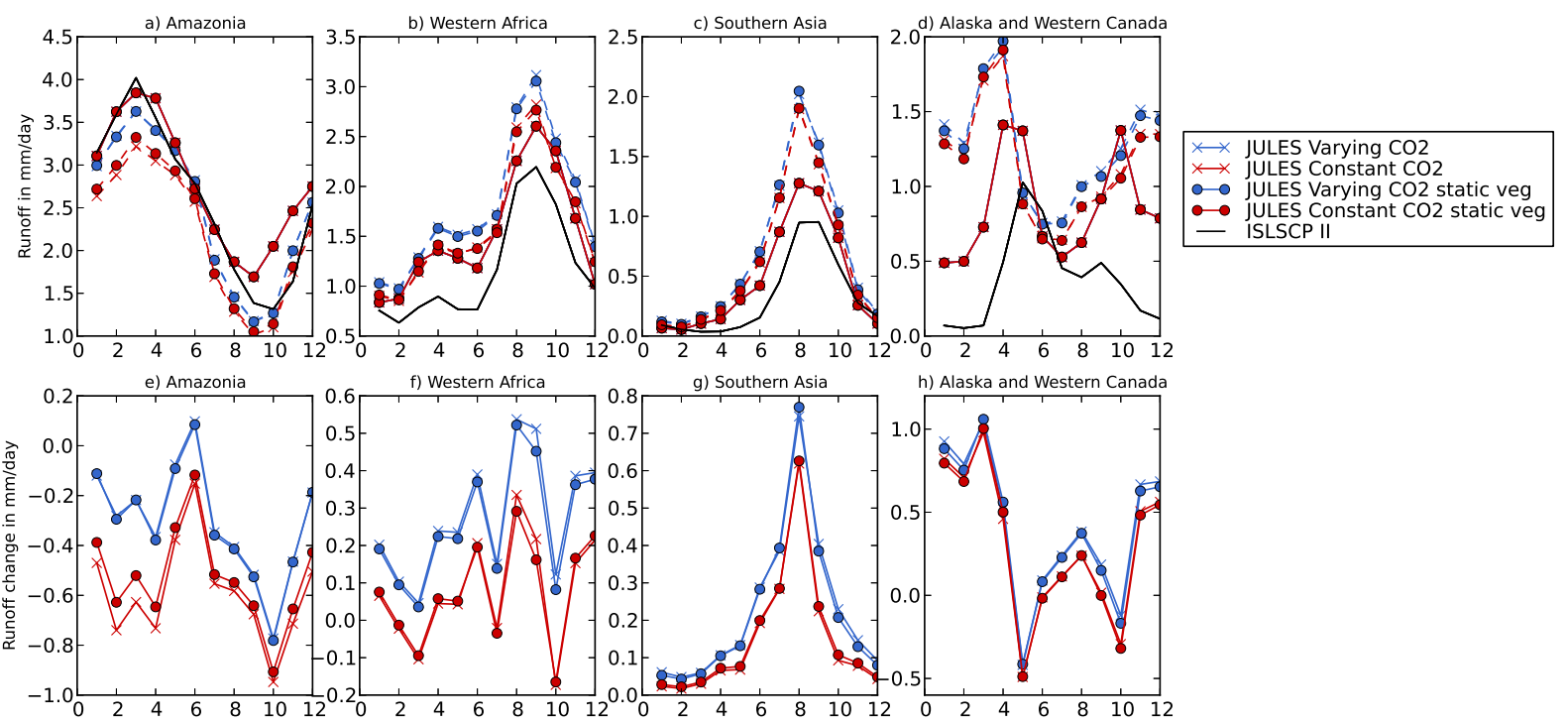

Fig. 8. Annual cycles of runoff for selected Giorgi regions using sensitivity experiment runs from JULES forced with HadGEM2-ES RCP8.5 climate: (a-d): absolute values for 1981-1990 (solid lines) and 2081-2090 (dashed lines); (e-h): absolute changes between 1981-1990 and 2081-2090.

less to the differences between the biome and hydrological models' runoff change projections.

\section{Limitations and future work}

Only changes in annual and monthly means were considered, which do not account for changes in extremes linked to runoff, such as floods (Dankers et al., 2013) and drought (Taylor et al., 2013; Prudhomme et al., 2013). Differences between biome and hydrological model projections may not show the same patterns for the extremes as they did for the mean changes. Nevertheless, in the ISI-MIP simulations, Prudhomme et al. (2013) noted smaller runoff deficits (less time is projected to be spent with runoff values below the $Q_{90}$ threshold of daily runoff calculated for the reference period) projected by the impact model JULES under elevated $\mathrm{CO}_{2}$, compared to fixed $\mathrm{CO}_{2}$, while JULES with both fixed vegetation distribution and constant $\mathrm{CO}_{2}$ behaved most like the hydrological models.

Use of spatial means using Giorgi region averages was beneficial for the aims of this study, however has some deficiencies. For instance in some cases, the simple boxes used result in spatial averaging over regions where precipitation is projected to increase and decrease. On a sub-region scale within Giorgi regions, there may be robust and plausible hydrological responses, which would not be captured through spatial averaging. Other papers have also used relatively large regions rather than river basins; for example, Betts et al. (2007) and Gedney et al. (2006) both consider runoff at the continental scale rather than at a river basin scale. When comparing results from other ISI-MIP papers which considered runoff or discharge with our general findings, the choice of Giorgi region scale rather than river basin scale would be unlikely to alter the overall conclusions. For example, (Schewe et al., 2013) considered runoff at a country scale (calculated using basins) and global scale, and found that JULES and LPJmL had a lower proportion of the global population under water stress than the other hydrological models in the future, which is in agreement with our findings. Prudhomme et al. (2013) considered runoff at a global scale and GEO sub-region scale, and drew similar conclusions when considering JULES in relation to the other hydrological models.

We have found that there were differences in runoff projections between models, but in order to determine the causes of these differences, other variables contributing to runoff rate such as evapotranspiration, snow mass, leaf area index and plant functional type fractions could be investigated systematically (Haddeland et al., 2011), even though the complicated interactions between the various processes make it infeasible to explain the causes of many simulation differences in detail, as noted in previous model intercomparisons (e.g. Koster and Milly, 1997).

Key uncertainties in projections of future runoff come from the possible changes in climate (GCM uncertainty), changes in vegetation and the runoff responses determined by the impacts models. As these findings used bias-corrected HadGEM2-ES climate forcing data, runoff responses using forcing data which has not been bias corrected may differ (Kahana et al., 2013) and using forcing data from other GCMs and representative concentration pathways may also influence runoff projections differently to HadGEM2-ES RCP 8.5 (Schewe et al., 2013). Although the present study 
has only considered one future scenario (RCP8.5), Tang and Lettenmaier (2012) found that spatial patterns of runoff sensitivity are stable across emissions scenarios, which suggests that there would be spatial similarities if this analysis were repeated for a different scenario. In a similar analysis for RCP2.6, the spatial patterns of changes, as well as the differences between the two types of model, were indeed fairly similar, although the magnitude of changes were smaller under the mitigation scenario (Davie et al., 2013).

The methods we have used for validation within this study were only to give a broad picture of how the models perform compared with observationally constrained data and hence conclusions are limited, as the models were not driven with observed precipitation, which explains some of the difference in magnitude, and also the ISLSCP II UNH/GRDC composite field would not ideally be used as a whole for validation. Therefore, more detailed comparison of simulated water balance terms with observational data (e.g. Haddeland et al., 2011; Falloon et al., 2011) would provide further insight into the reasons for differences between the model projections discussed here. Many of the impact models considered in this study have been extensively validated previously (Falloon et al., 2011; Hagemann et al., 2013; Haddeland et al., 2011). However, for land surface processes, validation does not necessarily help to constrain the future spread of projections - a wide range of future outcomes may result, despite reasonable simulation of present-day values (e.g. for water: Haddeland et al., 2011; Hagemann et al., 2013; Wada et al., 2013b, and for ecosystems and the carbon cycle: Good et al., 2012; Nishina et al., 2013).

This study has only assessed runoff projections and not any of the associated socioeconomic impacts (for example, assessing impacts on water stress - Schewe et al., 2013). Human interventions through land use change, irrigation and construction of dams and reservoirs may also affect future runoff, but have not been considered. Different impacts may also result from biome and hydrological models when fully coupled to GCMs as feedbacks can have a significant effect on projections (Falloon et al., 2012b; Martin and Levine, 2012).

\section{Summary and conclusions}

Our study has found notable differences in runoff projections between hydrological and biome models. In general, the biome models tended to produce larger increases and smaller decreases in regionally averaged annual mean runoff than hydrological models. However, there was much spread between the model projections within each category. Consensus for both types of model agreed on the sign of change across most of the world's land area. However in West Africa, the hydrological models tend to project drying whereas the biome models project a moistening. In some regions large differences in projections of changes in average runoff were found between impacts models, despite using common climate forcing data. The projected timing of runoff change for each category is similar, with the main difference being the magnitude at times of peak runoff.

The JULES simulations of sensitivity experiments with static vegetation distributions showed that the impacts of vegetation distribution change on runoff were generally much smaller than overall future projected changes in the period considered to 2100 . We found that in some regions, runoff changed in the direction which would be expected for the change in vegetation type, however in others it did not, so other factors outweighed the influence of vegetation change on runoff.

Interestingly, the impact of elevated $\mathrm{CO}_{2}$ on runoff in the four biome models studied here was not consistent. Two models showed increases and two decreases, with a larger spread between the projections with varying $\mathrm{CO}_{2}$ than constant $\mathrm{CO}_{2}$. These differences in model behaviour are affected by two competing processes, which vary in strength across the models, that of elevated $\mathrm{CO}_{2}$ on stomatal conductance and the fertilising impact on transpiration. In some regions, models projected differences between the varying $\mathrm{CO}_{2}$ and constant $\mathrm{CO}_{2}$ runs which were as large as the magnitude of change over time. The differences were largest at times of high runoff and the timing of runoff change throughout the year was similar.

The biome models which increased runoff from varying $\mathrm{CO}_{2}$, JULES and LPJmL, were also most dissimilar to the hydrological models in their projections. Therefore, the effects of $\mathrm{CO}_{2}$ on runoff add to the uncertainty in model projections, and partly explain differences between the hydrological and biome models' projections. The spatial and seasonal patterns of runoff change are also similar. Broadly, regions which showed most difference between the biome and hydrological models also projected most difference between the varying and constant $\mathrm{CO}_{2}$ runs. Seasonally the differences between model types or sensitivity experiments tended to be greatest at times of high runoff. The impact of varying $\mathrm{CO}_{2}$ was much larger than the impact of a changing vegetation distribution and so contributes more to explaining the differences between the biome and hydrological models.

To account for the full range of uncertainty, climate impact studies should consider a range of impact models. In planning studies of water resource management into the future, biome models which include $\mathrm{CO}_{2}$ effects and dynamic vegetation should be used in conjunction with hydrological models, as this will better show the full range of uncertainty in these projections which should not be ignored.

\section{Supplementary material related to this article is available online at http://www.earth-syst-dynam.net/4/ 359/2013/esd-4-359-2013-supplement.pdf.}


Acknowledgements. This work has been conducted under the framework of ISI-MIP. The ISI-MIP Fast Track project was funded by the German Federal Ministry of Education and Research (BMBF) with project funding reference number 01LS1201A. Responsibility for the content of this publication lies with the author. The role of J. C. S. Davie, P. D. Falloon, R. Kahana, R. Betts and R. Dankers was also supported by the Joint DECC/Defra Met Office Hadley Centre Climate Programme (GA01101). A. Ito, Y. Masaki and K. Nishina were supported by the Environment Research and Technology Development Fund (S-10) of the Ministry of the Environment, Japan. We acknowledge the World Climate Research Programme's Working Group on Coupled Modelling, which is responsible for CMIP, and we thank the HadGEM2-ES climate modeling group at the Met Office Hadley Centre for producing and making available their model output. For CMIP the US Department of Energy's Program for Climate Model Diagnosis and Intercomparison provides coordinating support and led development of software infrastructure in partnership with the Global Organization for Earth System Science Portals.

Edited by: W. Lucht

\section{References}

Alcamo, J., Döll, P., Henrichs, T., Kaspar, F., Lehner, B., Rösch, T., and Siebert, S.: Development and testing of the WaterGAP 2 global model of water use and availability, Hydrol. Sci. J., 48, 317-337, doi:10.1623/hysj.48.3.317.45290, 2003.

Alkama, R., Kageyama, M., and Ramstein, G.: Relative contributions of climate change, stomatal closure, and leaf area index changes to 20th and 21st century runoff change: A modelling approach using the Organizing Carbon and Hydrology in Dynamic Ecosystems (ORCHIDEE) land surface model, J. Geophys. Res., 115, D17112, doi:10.1029/2009jd013408, 2010.

Alo, C. A. and Wang, G.: Potential future changes of the terrestrial ecosystem based on climate projections by eight general circulation models, J. Geophys. Res., 113, G01004, doi:10.1029/2007jg000528, 2008.

Bates, B. C., Kundzewicz, Z. W., Palutikof, J., Shaohong, W., World, United, and Intergovernmental: Climate change and water [Electronic resource] : IPCC Technical paper VI., IPCC Secretariat, available at: http://www.worldcat.org/oclc/271816538, 2008.

Best, M. J., Pryor, M., Clark, D. B., Rooney, G. G., Essery, R. L. H., Ménard, C. B., Edwards, J. M., Hendry, M. A., Porson, A., Gedney, N., Mercado, L. M., Sitch, S., Blyth, E., Boucher, O., Cox, P. M., Grimmond, C. S. B., and Harding, R. J.: The Joint UK Land Environment Simulator (JULES), Model description - Part 1: Energy and water fluxes, Geosci. Model Dev. Discuss., 4, 595640, doi:10.5194/gmdd-4-595-2011, 2011.

Betts, R. A., Boucher, O., Collins, M., Cox, P. M., Falloon, P. D., Gedney, N., Hemming, D. L., Huntingford, C., Jones, C. D., Sexton, D. M. H., and Webb, M. J.: Projected increase in continental runoff due to plant responses to increasing carbon dioxide, Nature, 448, 1037-1041, doi:10.1038/nature06045, 2007.

Biemans, H., Hutjes, R. W. A., Kabat, P., Strengers, B. J., Gerten, D., and Rost, S.: Effects of Precipitation Uncertainty on Discharge Calculations for Main River Basins, J. Hydrometeor, 10, 1011-1025, doi:10.1175/2008jhm1067.1, 2009.
Bondeau, A., Smith, P. C., Zaehle, S., Schaphoff, S., Lucht, W., Cramer, W., Gerten, D., Lotze-Campen, H., Müller, C., Reichstein, M., and Smith, B.: Modelling the role of agriculture for the 20th century global terrestrial carbon balance, Global Change Biol., 13, 679-706, doi:10.1111/j.13652486.2006.01305.x, 2007.

Caesar, J., Palin, E., Liddicoat, S., Lowe, J., Burke, E., Pardaens, A., Sanderson, M., and Kahana, R.: Response of the HadGEM2 Earth System Model to future greenhouse gas emissions pathways to the year 2300., J. Climate, doi:10.1175/jcli-d12-00577.1, 2012.

Cao, L., Bala, G., Caldeira, K., Nemani, R., and Ban-Weiss, G.: Importance of carbon dioxide physiological forcing to future climate change, Proc. Natl. Acad. Sci., 107, 9513-9518, doi:10.1073/pnas.0913000107, 2010.

Clark, D. B., Mercado, L. M., Sitch, S., Jones, C. D., Gedney, N., Best, M. J., Pryor, M., Rooney, G. G., Essery, R. L. H., Blyth, E., Boucher, O., Harding, R. J., Huntingford, C., and Cox, P. M.: The Joint UK Land Environment Simulator (JULES), model description - Part 2: Carbon fluxes and vegetation dynamics, Geosci. Model Dev., 4, 701-722, doi:10.5194/gmd-4-701-2011, 2011.

Collins, W. J., Bellouin, N., Doutriaux-Boucher, M., Gedney, N., Halloran, P., Hinton, T., Hughes, J., Jones, C. D., Joshi, M., Liddicoat, S., Martin, G., O'Connor, F., Rae, J., Senior, C., Sitch, S., Totterdell, I., Wiltshire, A., and Woodward, S.: Development and evaluation of an Earth-system model - HadGEM2, Geosci. Model Dev. Discuss., 4, 997-1062, doi:10.5194/gmdd-4-9972011, 2011.

Dankers, R., Clark, D., Falloon, P., Heinke, J., Fekete, B. M., Gosling, S., Masaki, Y., and Stacke, T.: A first look at changes in flood hazard in the ISI-MIP ensemble, Proc. Natl. Acad. Sci. accepted, 2013.

Davie, J., Falloon, P., Kahana, R., Dankers, R., Betts, R., Portmann, F., Clark, D., Ito, A., Masaki, Y., Nishina, K., Fekete, B., Tessler, Z., Liu, X., Tang, Q., Hagemann, S., Stacke, T., Pavlick, R., Schaphoff, S., Gosling, S., Franssen, W., and Arnell, N., Comparing projections of future changes in runoff from hydrological and ecosystem models in ISI-MIP for the "aggressive mitigation" scenario RCP2.6, compared with RCP8.5, in: Impacts World 2013 Conference Proceedings, Potsdam: Potsdam Institute for Climate Impact Research, 350-362, doi:10.2312/pik.2013.001, 2013.

Döll, P., Kaspar, F., and Lehner, B.: A global hydrological model for deriving water availability indicators: model tuning and validation, J. Hydrol., 270, 105-134, doi:10.1016/s00221694(02)00283-4, 2003.

Döll, P., Hoffmann-Dobrev, H., Portmann, F. T., Siebert, S., Eicker, A., Rodell, M., Strassberg, G., and Scanlon, B. R.: Impact of water withdrawals from groundwater and surface water on continental water storage variations, J. Geodynam., 59-60, 143-156, doi:10.1016/j.jog.2011.05.001, 2012.

Ehret, U., Zehe, E., Wulfmeyer, V., Warrach-Sagi, K., and Liebert, J.: HESS Opinions "Should we apply bias correction to global and regional climate model data?", Hydrol. Earth Syst. Sci., 16, 3391-3404, doi:10.5194/hess-16-3391-2012, 2012.

Falloon, P. D. and Betts, R. A.: The impact of climate change on global river flow in HadGEM1 simulations, Atmosph. Sci. Lett., 7, 62-68, doi:10.1002/asl.133, 2006. 
Falloon, P., Betts, R., Wiltshire, A., Dankers, R., Mathison, C., McNeall, D., Bates, P., and Trigg, M.: Validation of River Flows in HadGEM1 and HadCM3 with the TRIP River Flow Model, J. Hydrometeor, 12, 1157-1180, doi:10.1175/2011JHM1388.1, 2011.

Falloon, P. D., Dankers, R., Betts, R. A., Jones, C. D., Booth, B. B. B., and Lambert, F. H.: Role of vegetation change in future climate under the A1B scenario and a climate stabilisation scenario, using the HadCM3C Earth system model, Biogeosci., 9, 4739-4756, doi:10.5194/bg-9-4739-2012, 2012a.

Falloon, P. D., Dankers, R., Betts, R. A., Jones, C. D., Booth, B. B. B., and Lambert, F. H.: Role of vegetation change in future climate under the A1B scenario and a climate stabilisation scenario, using the HadCM3C earth system model, Biogeosci. Discuss., 9, 7601-7659, doi:10.5194/bgd-9-7601-2012, 2012b.

Fekete, B. and Vorosmarty, C. J.: ISLSCP II UNH/GRDC Composite Monthly Runoff, in: ISLSCP Initiative II Collection, edited by: Hall, F. G., Collatz, G., Meeson, B., Los, S., Brown de Colstoun, E., and Landis, D., Data set, available at: http: //daac.ornl.gov/, from Oak Ridge National Laboratory Distributed Active Archive Center, Oak Ridge, Tennessee, USA, doi:10.3334/ORNLDAAC/994, 2011.

Fekete, B., Vorosmarty, C., and Grabs, W.: Global, Composite Runoff Fields Based on Observed River Discharge and Simulated Water Balances, Tech. rep., GRDC Report 22, Global Runoff Data Center, Koblenz, Germany, 1999.

Fekete, B. M., Vörösmarty, C. J., and Grabs, W.: High-resolution fields of global runoff combining observed river discharge and simulated water balances, Global Biogeochem. Cy., 16, 15-1510, doi:10.1029/1999gb001254, 2002.

Flörke, M., Kynast, E., Bärlund, I., Eisner, S., Wimmer, F., and Alcamo, J.: Domestic and industrial water uses of the past 60 years as a mirror of socio-economic development: A global simulation study, Global Environ. Change, 23, 144-156, doi:10.1016/j.gloenvcha.2012.10.018, 2013.

Fraedrich, K., Jansen, H., Kirk, E., and Lunkeit, F.: The Planet Simulator: Green planet and desert world, Meteorolog. Z., 14, 305314, doi:10.1127/0941-2948/2005/0044, 2005.

Friend, A. D., Betts, R., Cadule, P., Ciais, P., Clark, D., Dankers, R., Falloon, P., Itoh, A., Kahana, R., Keribin, R. M., Kleidon, A., Lomas, M. R., Lucht, W., Nishina, K., Ostberg, S., Pavlick, R., Peylin, P., Rademacher, T. T., Schaphoff, S., Vuichard, N., Warszawski, L., Wiltshire, A., and Woodward, F. I.: Carbon residence time dominates uncertainty in terrestrial vegetation responses to future climate and atmospheric $\mathrm{CO}_{2}$, Proc. Natl. Acad. Sci. USA, accepted, 2013.

Gedney, N., Cox, P. M., Betts, R. A., Boucher, O., Huntingford, C., and Stott, P. A.: Detection of a direct carbon dioxide effect in continental river runoff records, Nature, 439, 835-838, doi:10.1038/nature04504, 2006.

Giorgi, F. and Bi, X.: Updated regional precipitation and temperature changes for the 21 st century from ensembles of recent AOGCM simulations, Geophys. Res. Lett., 32, L21715, doi:10.1029/2005g1024288, 2005.

Good, P., Jones, C., Lowe, J., Betts, R., and Gedney, N.: Comparing Tropical Forest Projections from Two Generations of Hadley Centre Earth System Models, HadGEM2-ES and HadCM3LC, J. Climate, 26, 495-511, doi:10.1175/jcli-d-11-00366.1, 2012.
Gosling, S. N. and Arnell, N. W.: Simulating current global river runoff with a global hydrological model: model revisions, validation, and sensitivity analysis, Hydrol. Process., 25, 1129-1145, doi:10.1002/hyp.7727, 2011.

Gosling, S. N., Bretherton, D., Haines, K., and Arnell, N. W.: Global hydrology modelling and uncertainty: running multiple ensembles with a campus grid, Philos. T. R. So. A, 368, 4005-4021, doi:10.1098/rsta.2010.0164, 2010.

Haddeland, I., Clark, D. B., Franssen, W., Ludwig, F., Voß, F., Arnell, N. W., Bertrand, N., Best, M., Folwell, S., Gerten, D., Gomes, S., Gosling, S. N., Hagemann, S., Hanasaki, N., Harding, R., Heinke, J., Kabat, P., Koirala, S., Oki, T., Polcher, J., Stacke, T., Viterbo, P., Weedon, G. P., and Yeh, P.: Multimodel Estimate of the Global Terrestrial Water Balance: Setup and First Results, J. Hydrometeor, 12, 869-884, doi:10.1175/2011jhm1324.1, 2011.

Hagemann, S. and Gates, L. D.: Improving a subgrid runoff parameterization scheme for climate models by the use of high resolution data derived from satellite observations, Clim. Dynam., 21, 349-359, doi:10.1007/s00382-003-0349-x, 2003.

Hagemann, S., Chen, C., Clark, D. B., Folwell, S., Gosling, S. N., Haddeland, I., Hanasaki, N., Heinke, J., Ludwig, F., Voss, F., and Wiltshire, A. J.: Climate change impact on available water resources obtained using multiple global climate and hydrology models, Earth Syst. Dynam., 4, 129-144, doi:10.5194/esd4-129-2013, 2013.

Hall, F. G., Brown de Colstoun, E., Collatz, G. J., Landis, D., Dirmeyer, P., Betts, A., Huffman, G. J., Bounoua, L., and Meeson, B.: ISLSCP Initiative II global data sets: Surface boundary conditions and atmospheric forcings for land-atmosphere studies, J. Geophys. Res., 111, D22S01, doi:10.1029/2006jd007366, 2006.

Hanasaki, N., Kanae, S., Oki, T., Masuda, K., Motoya, K., Shirakawa, N., Shen, Y., and Tanaka, K.: An integrated model for the assessment of global water resources - Part 1: Model description and input meteorological forcing, Hydrol. Earth Syst. Sci., 12, 1007-1025, doi:10.5194/hess-12-1007-2008, 2008a.

Hanasaki, N., Kanae, S., Oki, T., Masuda, K., Motoya, K., Shirakawa, N., Shen, Y., and Tanaka, K.: An integrated model for the assessment of global water resources - Part 2: Applications and assessments, Hydrol. Earth Syst. Sci., 12, 1027-1037, doi:10.5194/hess-12-1027-2008, 2008b.

Hempel, S., Frieler, K., Warszawski, L., Schewe, J., and Piontek, F.: A trend-preserving bias correction - the ISI-MIP approach, Earth Syst. Dynam., 4, 219-236, doi:10.5194/esd-4-219-2013, 2013.

Ito, A. and Inatomi, M.: Water-Use Efficiency of the Terrestrial Biosphere: A Model Analysis Focusing on Interactions between the Global Carbon and Water Cycles, J. Hydrometeor, 13, 681-694, doi:10.1175/jhm-d-10-05034.1, 2011.

Jones, C., Lowe, J., Liddicoat, S., and Betts, R.: Committed terrestrial ecosystem changes due to climate change, Nat. Geosci., 2, 484-487, doi:10.1038/ngeo555, 2009.

Jones, C., Liddicoat, S., and Lowe, J.: Role of terrestrial ecosystems in determining $\mathrm{CO}_{2}$ stabilization and recovery behaviour, Tellus B, 62, 682-699, doi:10.1111/j.1600-0889.2010.00490.x, 2010.

Jones, C. D., Hughes, J. K., Bellouin, N., Hardiman, S. C., Jones, G. S., Knight, J., Liddicoat, S., O’Connor, F. M., Andres, R. J., Bell, C., Boo, K. O., Bozzo, A., Butchart, N., Cadule, P., Corbin, K. D., Doutriaux-Boucher, M., Friedlingstein, P., Gornall, J., 
Gray, L., Halloran, P. R., Hurtt, G., Ingram, W. J., Lamarque, J. F., Law, R. M., Meinshausen, M., Osprey, S., Palin, E. J., Chini, L. P., Raddatz, T., Sanderson, M. G., Sellar, A. A., Schurer, A., Valdes, P., Wood, N., Woodward, S., Yoshioka, M., and Zerroukat, M.: The HadGEM2-ES implementation of CMIP5 centennial simulations, Geosci. Model Dev., 4, 543-570, doi:10.5194/gmd-4-543-2011, 2011.

Kahana, R., Dankers, R., Davie, J. C. S., and Falloon, P. D.: The effect of bias correction on future runoff projections in the JULES model, Earth System Dynamics, in preparation, 2013.

Kaye, N. R., Hartley, A., and Hemming, D.: Mapping the climate: guidance on appropriate techniques to map climate variables and their uncertainty, Geosci. Model Dev. Discuss., 4, 1875-1906, doi:10.5194/gmdd-4-1875-2011, 2011.

Koster, R. D. and Milly, P. C. D.: The Interplay between Transpiration and Runoff Formulations in Land Surface Schemes Used with Atmospheric Models, J. Climate, 10, 1578-1591,doi:10.1175/15200442(1997)010<3C1578:tibtar>3E2.0.co;2, 1997.

Kundzewicz, Z. W., Mata, L. J., Arnell, N. W., Döll, P., Kabat, P., Jiménez, B., Miller, K. A., Oki, T., Sen, Z., and Shiklomanov, I. A.: Freshwater resources and their management, in: Climate Change 2007: Impacts, Adaptation and Vulnerability Contribution of Working Group II to the Fourth Assessment Report of the Intergovernmental Panel on Climate Change, edited by: Parry, M. L., Canziani, O. F., Palutikof, J. P., van der Linden, P. J., and Hanson, C. E., 173-210, Cambridge University Press, Cambridge, UK, 2007.

Leipprand, A. and Gerten, D.: Global effects of doubled atmospheric $\mathrm{CO}_{2}$ content on evapotranspiration, soil moisture and runoff under potential natural vegetation, Hydrol. Sci. J., 51, 171-185, doi:10.1623/hysj.51.1.171, 2006.

Liang, X., Lettenmaier, D. P., Wood, E. F., and Burges, S. J.: A simple hydrologically based model of land surface water and energy fluxes for general circulation models, J. Geophys. Res., 99, 14415-14428, doi:10.1029/94jd00483, 1994.

Martin, G. M. and Levine, R. C.: The influence of dynamic vegetation on the present-day simulation and future projections of the South Asian summer monsoon in the HadGEM2 family, Earth Syst. Dynam., 3, 245-261, doi:10.5194/esd-3-245-2012, 2012.

Martin, G. M., Bellouin, N., Collins, W. J., Culverwell, I. D., Halloran, P. R., Hardiman, S. C., Hinton, T. J., Jones, C. D., McDonald, R. E., McLaren, A. J., O'Connor, F. M., Roberts, M. J., Rodriguez, J. M., Woodward, S., Best, M. J., Brooks, M. E., Brown, A. R., Butchart, N., Dearden, C., Derbyshire, S. H., Dharssi, I., Doutriaux-Boucher, M., Edwards, J. M., Falloon, P. D., Gedney, N., Gray, L. J., Hewitt, H. T., Hobson, M., Huddleston, M. R., Hughes, J., Ineson, S., Ingram, W. J., James, P. M., Johns, T. C., Johnson, C. E., Jones, A., Jones, C. P., Joshi, M. M., Keen, A. B., Liddicoat, S., Lock, A. P., Maidens, A. V., Manners, J. C., Milton, S. F., Rae, J. G. L., Ridley, J. K., Sellar, A., Senior, C. A., Totterdell, I. J., Verhoef, A., Vidale, P. L., and Wiltshire, A.: The HadGEM2 family of Met Office Unified Model climate configurations, Geosci. Model Dev., 4, 723-757, doi:10.5194/gmd-4723-2011, 2011.

McSweeney, C. F. and Jones, R. G.: No consensus on consensus: The challenge of finding a universal approach to measuring and mapping ensemble consistency in GCM projections, Clim. Change, 199, 617-629, doi:10.1007/510584-013-0781-9, 2013.
Meehl, G. A., Stocker, T. F., Collins, W. D., Friedlingstein, P., Gaye, A. T., Gregory, J. M., Kitoh, A., Knutti, R., Murphy, J. M., Noda, A., Raper, S. C. B., Watterson, I. G., Weaver, A. J., and Zhao, Z. C.: Global Climate Projections, in: Climate Change 2007: The Physical Science Basis. Contribution of Working Group I to the Fourth Assessment Report of the Intergovernmental Panel on Climate Change, edited by: Solomon, S., Qin, D., Manning, M., Chen, Z., Marquis, M., Averyt, K. B., Tignor, M., and Miller, H. L., Chap. 10, Cambridge University Press, 2007.

Micheels, A., Eronen, J., and Mosbrugger, V.: The Late Miocene climate response to a modern Sahara desert, Global Planet. Change, 67, 193-204, doi:10.1016/j.gloplacha.2009.02.005, 2009.

Moss, R. H., Edmonds, J. A., Hibbard, K. A., Manning, M. R., Rose, S. K., van Vuuren, D. P., Carter, T. R., Emori, S., Kainuma, M., Kram, T., Meehl, G. A., Mitchell, J. F. B., Nakicenovic, N., Riahi, K., Smith, S. J., Stouffer, R. J., Thomson, A. M., Weyant, J. P., and Wilbanks, T. J.: The next generation of scenarios for climate change research and assessment, Nature, 463, 747-756, doi:10.1038/nature08823, 2010.

Niklaus, P. A. and Falloon, P.: Estimating soil carbon sequestration under elevated $\mathrm{CO}_{2}$ by combining carbon isotope labelling with soil carbon cycle modelling, Global Change Biol., 12, 19091921, doi:10.1111/j.1365-2486.2006.01215.x, 2006.

Nishina, K., Ito, A., Beerling, D. J., Cadule, P., Ciais, P., Clark, D. B., Falloon, P., Friend, A. D., Kahana, R., Kato, E., Keribin, R., Lucht, W., Lomas, M., Rademacher, T. T., Pavlick, R., Schaphoff, S., Vuichard, N., Warszawaski, L., and Yokohata, T.: Global soil organic carbon stock projection uncertainties relevant to sensitivity of global mean temperature and precipitation changes, Earth Syst. Dynam. Discuss., 4, 1035-1064, doi:10.5194/esdd-4-10352013, 2013.

O'ishi, R. and Abe-Ouchi, A.: Influence of dynamic vegetation on climate change and terrestrial carbon storage in the Last Glacial Maximum, Clim. Past Discuss., 8, 5787-5816, doi:10.5194/cpd8-5787-2012, 2012.

Pavlick, R., Drewry, D. T., Bohn, K., Reu, B., and Kleidon, A.: The Jena Diversity-Dynamic Global Vegetation Model (JeDiDGVM): a diverse approach to representing terrestrial biogeography and biogeochemistry based on plant functional tradeoffs, Biogeosci., 10, 4137-4177, doi:10.5194/bg-10-4137-2013, 2013.

Prudhomme, C., Robinson, E., Giuntoli, I., Clark, D. B., Arnell, N., Dankers, R., Fekete, B., Franssen, W., Gosling, S., Hagemann, S., Hannah, D. M., Kim, H., Konzmann, M., Masaki, Y., Satoh, Y., Stacke, T., Wada, Y., and Wisser, D.: A global analysis of modelled runoff deficits for the 21 st century under alternative Representative Concentration Pathways: uncertainty and hotspots, Proc. Natl. Acad. Sci., accepted, 2013.

Rost, S., Gerten, D., Bondeau, A., Lucht, W., Rohwer, J., and Schaphoff, S.: Agricultural green and blue water consumption and its influence on the global water system, Water Resour. Res., 44, W09405, doi:10.1029/2007wr006331, 2008.

Ruosteenoja, K.: Future climate in world regions : an intercomparison of model-based projections for the new IPCC emissions scenarios, Suomen ympäristo, 644, Finnish Environment Institute : Edita, jakaja, available at: http://www.worldcat.org/isbn/ 9521114649, 2003. 
Schewe, J., Heinke, J., Gerten, D., Haddeland, I., Clark, D., Dankers, R., Eisner, S., Fekete, B., Gosling, S., Kim, H., Liu, X., Masaki, Y., Portmann, F. T., Satoh, Y., Stacke, T., Tang, Q., Wada, Y., Wisser, D., Albrecht, T., Frieler, K., Piontek, F., and Warszawski, L.: Multi-model assessment of water scarcity under climate change, Proc. Natl. Acad. Sci., accepted, 2013.

Stacke, T. and Hagemann, S.: Development and evaluation of a global dynamical wetlands extent scheme, Hydrol. Earth Syst. Sci., 16, 2915-2933, doi:10.5194/hess-16-2915-2012, 2012.

Swann, A. L., Fung, I. Y., Levis, S., Bonan, G. B., and Doney, S. C.: Changes in Arctic vegetation amplify high-latitude warming through the greenhouse effect, Proc. Natl. Acad. Sci., 107, 1295-1300, doi:10.1073/pnas.0913846107, 2010.

Tang, Q. and Lettenmaier, D. P.: 21st century runoff sensitivities of major global river basins, Geophys. Res. Lett., 39, L06403, doi:10.1029/2011g1050834, 2012.

Tang, Q., Oki, T., and Kanae, S.: A distributed biosphere hydrological model (DBHM) for large river basin, Proc. Hydraul. Eng., 50, 37-42, doi:10.2208/prohe.50.37, 2006.

Tang, Q., Oki, T., Kanae, S., and Hu, H.: The Influence of Precipitation Variability and Partial Irrigation within Grid Cells on a Hydrological Simulation, J. Hydrometeor, 8, 499-512, doi:10.1175/jhm589.1, 2007.

Taylor, I. H., Burke, E., McColl, L., Falloon, P. D., Harris, G. R., and McNeall, D.: The impact of climate mitigation on projections of future drought, Hydrol. Earth Syst. Sci., 17, 2339-2358, doi:10.5194/hess-17-2339-2013, 2013.

van Beek, L. P. H., Wada, Y., and Bierkens, M. F. P.: Global monthly water stress: 1. Water balance and water availability, Water Resour. Res., 47, W07517, doi:10.1029/2010wr009791, 2011.
Vörösmarty, C. J., Federer, C. A., and Schloss, A. L.: Potential evaporation functions compared on US watersheds: Possible implications for global-scale water balance and terrestrial ecosystem modeling, J. Hydrol., 207, 147-169, doi:10.1016/s00221694(98)00109-7, 1998.

Wada, Y., van Beek, L. P. H., and Bierkens, M. F. P.: Modelling global water stress of the recent past: on the relative importance of trends in water demand and climate variability, Hydrol. Earth Syst. Sci., 15, 3785-3808, doi:10.5194/hess-15-37852011, 2011.

Wada, Y., Wisser, D., and Bierkens, M. F. P.: Global modeling of withdrawal, allocation and consumptive use of surface water and groundwater resources, Earth Syst. Dynam. Discuss., 4, 355392, doi:10.5194/esdd-4-355-2013, 2013a.

Wada, Y., Wisser, D., Eisner, S., Flörke, M., Gerten, D., Haddeland, I., Hanasaki, N., Masaki, Y., Portmann, F. T., Stacke, T., Tessler, Z., and Schewe, J.: Multi-model projections and uncertainties of irrigation water demand under climate change, Geophys. Res. Lett., 40, doi:10.1002/grl.50686, 2013 b.

Warszawski, L., Frieler, K., Piontek, F., Schewe, J., and Serdeczny, O.: Research Design of the Intersectoral Impact Model Intercomparison Project (ISI-MIP), Proc. Natl. Acad. Sci., accepted, 2013.

Wiltshire, A., Gornall, J., Booth, B. B. B., Dennis, E., Falloon, P. D., Kay, G., McNeall, D., McSweeney, C., and Betts, R. A.: The importance of population, climate change and $\mathrm{CO}_{2}$ Change, Global Environ. Change, in press, doi:10.1016/j.gloenvcha.2013.06.005, 2013.

Zhang, L., Dawes, W. R., and Walker, G. R.: Response of mean annual evapotranspiration to vegetation changes at catchment scale, Water Resour. Res., 37, 701-708, doi:10.1029/2000wr900325, 2001. 